\title{
関節モーメント・角度を含めた下肢関節回転運動の定量的な解析手法の提案
}

\author{
林 祐一郎 ${ }^{* 1}$, 辻内 伸好 ${ }^{* 2}$, 中村 匠汰 ${ }^{* 3}$, 牧野 裕太 ${ }^{* 4}$ \\ 浅野 真由 ${ }^{* 3}$ ，松田 靖史 ${ }^{* 5}$ ，土屋 陽太郎 ${ }^{* 6}$
}

\section{Proposal of quantitative analysis method concerning rotational motion of lower limb joints including joint moments as well as joint angles}

\author{
Yuichiro HAYASHI ${ }^{* 1}$, Nobutaka TSUJIUCHI ${ }^{* 2}$, Shota NAKAMURA*3, Yuta MAKINO*4, \\ Mayu ASANO ${ }^{* 3}$, Yasushi MATSUDA ${ }^{* 5}$ and Youtaro TSUCHIYA ${ }^{* 6}$ \\ ${ }^{* 1}$ Department of Mechanical Engineering, Graduate School of Science and Engineering, Tokyo Metropolitan University \\ 1-1 Minami-Osawa, Hachioji-shi, Tokyo 192-0397, Japan \\ ${ }^{* 2, * 3, * 4}$ Department of Mechanical Engineering, Graduate School of Science and Engineering, Doshisha University \\ 1-3 Miyakodani, Tatara, Kyotanabe-shi, Kyoto 610-0394, Japan \\ ${ }^{* 5}$ Kawamura-Gishi Co., LTD. \\ 1-12-1 Goryo, Daitoh-shi, Osaka 574-0064, Japan \\ ${ }^{* 6}$ Tec-Gihan Co., LTD. \\ 1-22 Nishinohata, Okubo-cho, Uji-shi, Kyoto 611-0033, Japan
}

Received 23 June 2015

\begin{abstract}
In human gait motion analysis, which is one useful method for efficient physical rehabilitation to define various quantitative evaluation indices, joint angles and joint loads are measured during gait. Recently, it is thought that trans-femoral amputees with the prosthetic limb must regain motion pattern by refined rehabilitation program using joint moments as a representative joint loads and understanding them is indispensable for biomechanical consideration. On the other hand, human keeps a high correlation among the motion of all joints during gait. Joint motion analysis of the correlation extracts a few simultaneously activating segmental coordination patterns, and the structure of the intersegmental coordination is attracting attention to an expected relationship with a control strategy. However, when the evaluation method using singular value decomposition has been applied to only joint angles of the lower limb, joint moments related to the rotational motion of the joints have not yet been considered. In this paper, a novel quantitative analysis method concerning rotational motion of lower limb joints by using joint moments as well as joint angles aims to be proposed. Each parameter of the healthy subject and trans-femoral amputee is measured by using mobile force plate and attitude sensor, split-belt treadmill simultaneously and their motion patterns are analyzed by the proposed method. As a result of the experiments, patterns of each evaluation index are obtained as the remarkably different feature quantities between healthy subject and trans-femoral amputee especially pertaining to joint moments. Finally, the effectiveness of the quantitative analysis concerning human motion is validated.
\end{abstract}

Key words : Medical and welfare assistance, Biomechanics, Gait analysis, Singular value decomposition, Joint moment, Trans-femoral amputee, Split-belt treadmill

1. 緒言

ヒトの歩行運動は身体の力学, 周囲の環境および中枢神経系によるシステムであり, それらの相互作用から不 安定な床面においても姿勢を維持できる安定性, 傾斜や歩行速度の変化に応じて動きを調整する適応性の両面が

No.15-00344 [DOI:10.1299/transjsme.15-00344], J-STAGE Advance Publication date : 15 January, 2016

*1 正員, 首都大学東京大学院 理工学研究科 機械工学専攻（下192-0397 東京都八王子市南大沢 1-1）

*2 正員, フェロー, 同志社大学 理工学部 機械システム工学科（† 610-0394 京都府京田辺市多々羅都谷 1-3）

*3 正員, 同志社大学大学院 理工学研究科 機械工学専攻

$*_{4}$ 同志社大学大学院 理工学研究科 機械工学専攻

*5 川村義肢（株）（于574-0064 大阪府大東市御領 1-12-1)

*6 （株）テック技販（广611-0033 京都府宇治市大久保町西ノ端 1-22）

E-mail of corresponding author: hayashiy@tmu.ac.jp 
Hayashi, Tsujiuchi, Nakamura, Makino, Asano, Matsuda and Tsuchiya,

Transactions of the JSME (in Japanese), Vol.82, No.834 (2016)

実現されている(舩戸他，2010). また，近年では疾病や労働災害・交通事故による下肢切断などの歩行障害を有 する患者が増加しており, 高齢化社会の到来と相まってリハビリテーション医療の重要性が高まってきている(北 村他, 2007; 佐藤他, 2008; 豊田他, 2008). ここで, 歩行障害の解明とそれらに基づく運動教示を考える上で, ヒトの制御方策に基づく運動の構成原理は重要であり，その巧みさを明らかにすることは機械の設計論としても 有用である.これまでに，ヒトの運動は複数の単純な協調パターンの重㸚合わせで成り立つと報告され(Ivanenko et al., 2008; 三嶋他，2011)，抽出した各パターンを提示することによって運動教示が容易となると考えられる.

先行研究として，ヒトの運動中に生じる関節角度や表面筋電位を算出し，それらの時間変化を各関節または筋 肉について整理した上，観測行列と呼ばれる評価指標を表す行列にまとめ，特異值分解を施すことによって，主 要な関節間協調およびその活動パターンを求める定量的評価手法が提案され, 歩行など種々の運動に適用されて いる(舩戸他，2013; 林他，2015). これにより，全身にわたる関節間の相互に高い相関が存在するヒトの運動に関 して存在する多数の運動学的パラメータについて，それらによって表現される関節間協調が何を表しているかの 具体的な性質を判断する場合において，複数の特徵量を用いて客観的に定義することが可能となる．しかし，提 案された手法の適用例では, 前述の物理量と同様にリハビリテーション医療の一環として実施される歩行訓練に おいて理学療法士が指示を与える上での定量的な評価指標となり，動力学的な決定因子と定義され非常に有用な 力覚情報である下肢の各関節モーメントが運動要素に含まれず, 関節周りにおける回転運動の構成原理が不明で あると考えられる.

そこで, 本研究ではヒトの歩行における下肢の動力学的パラメータとして関節モーメントに着目し, 姿勢制御 メカニズムとして考えられる各関節の回転運動パターンを関節角度・モーメントの双方を考慮した運動学ならび に動力学的な観点から定量的に解析, 評価可能な手法を新たに提案し, 実際の歩行運動に適用寸ることを目的と する. 最初に, サンダル型の移動式床反力計と加速度センサ, ジャイロセンサ, 地磁気センサを内蔵した姿勢セ ンサを用いたウェアラブルな歩行解析システム(足立他, 2012; 林他, 2013)ならびに左右分離式トレッドミルを用 いて, 健常者に加えて歩行障害者のうち下肢切断者の代表例としての被験者である大腿義足装着者の歩行運動を 計測する. 次に，それらより算出したそれぞれの関節角度および関節モーメントの時系列挙動を組み合わせて構 成される新たな観測行列に関して特異值分解を施し, 各物理量に基づく歩行中の下肢関節に生じる回転運動の寄 与度解析をおこない, 関節間協調動作の中でも相関が高い動作パターンを抽出する. そして, 最終的には健常者 と大腿義足装着者との動作パターンに関する相互比較をおこない，実施した定量的な解析の有効性を検証する.

\section{2. 提案手法}

本研究では, ヒトの歩行中における下肢の関節周りに生じる回転運動をはじめとする関節間協調動作を定量的 に解析寸るため，これまでに提案された特異值分解の原理に基づく関節角度を用いた評価手法(舩戸他，2010)お よびその適用例(Funato et al., 2015)に加えて, 新たに関節モーメントの要素を含めた評価手法を提案する. これに より, 先行研究における運動学を考慮する際に必要不可欠な関節角度のみの特異值分解と異なり, 七トの歩行に とって重要な下肢関節回転運動に大きく寄与寸ると考えられる動力学としての代表的な物理量である関節モーメ ントを同時に特異值分解することで，各関節がどのような方向に運動し，その間に力を働かせているかといった 角度とモーメントの相互作用を考慮した上での主要な動作パターンをより精密な形で抽出でき, 原理的な解明と いう側面に加えてリハビリテーションなど運動に関する訓練の指標としてより実際的な数理科学的見地に基づく データならびに考察の結果が得られ, ヒトの歩行に関して工学的応用として実験的に検討できるといえる. 以下，

$\theta_{\text {ankle }}(t), \theta_{\text {knee }}(t), \theta_{\text {hip }}(t)$ を足, 膝, 股関節の関節角度, $M_{\text {ankle }}(t), M_{\text {knee }}(t), M_{h i p}(t)$ を足, 膝, 股関節に生じる 関節モーメントの時系列形式とする.これらを順番に並べた各関節周りに生じる関節角度と関節モーメントの算出 データを標準化した時系列パターン $\bar{\theta}_{j}\left(t_{i}\right), \bar{M}_{j}\left(t_{i}\right)(i=1, \ldots, m, j=1, \ldots, r \leq n)$ を用いて以下の行列式で表す.

$$
\overline{\boldsymbol{R}}(\bar{\theta}, \bar{M}, t)=\left(\begin{array}{cccccc}
\bar{\theta}_{1}\left(t_{1}\right) & \cdots & \bar{\theta}_{p}\left(t_{1}\right) & \bar{M}_{1}\left(t_{1}\right) & \cdots & \bar{M}_{q}\left(t_{1}\right) \\
\vdots & \ddots & \vdots & \vdots & \ddots & \vdots \\
\bar{\theta}_{1}\left(t_{m}\right) & \cdots & \bar{\theta}_{p}\left(t_{m}\right) & \bar{M}_{1}\left(t_{m}\right) & \cdots & \bar{M}_{q}\left(t_{m}\right)
\end{array}\right)
$$


Hayashi, Tsujiuchi, Nakamura, Makino, Asano, Matsuda and Tsuchiya,

Transactions of the JSME (in Japanese), Vol.82, No.834 (2016)

この行列を観測行列と定義する. $m, n, p, q$ はデータ数であり, $n(=p+q), p, q \in r$ とする. 次に, 観測行列 $\overline{\boldsymbol{R}}(\bar{\theta}, \bar{M}, t)$ に対して特異值分解を施す．特異值分解を用いて，関節角度と関節モーメントを互いに直交する基 底ベクトルで展開している. ここで, $\overline{\boldsymbol{R}}(\bar{\theta}, \bar{M}, t)$ の特異值を $\lambda_{j}, \overline{\boldsymbol{R}}(\bar{\theta}, \bar{M}, t) \overline{\boldsymbol{R}}(\bar{\theta}, \bar{M}, t)^{T}$ の特異ベクトルを $\boldsymbol{v}_{j}(t), \overline{\boldsymbol{R}}(\bar{\theta}, \bar{M}, t)^{T} \overline{\boldsymbol{R}}(\bar{\theta}, \bar{M}, t)$ の特異ベクトルを $\mathbf{z}_{j}(\bar{\theta}, \bar{M})$ とすると， $\overline{\boldsymbol{R}}(\bar{\theta}, \bar{M}, t)$ は次式で表せる.

$$
\overline{\boldsymbol{R}}(\bar{\theta}, \bar{M}, t)=\sum_{j=1}^{n} \lambda_{j} \cdot \boldsymbol{v}_{j}(t) \cdot \mathbf{z}_{j}{ }^{T}(\bar{\theta}, \bar{M})
$$

ここで, $\lambda_{j}$ は特異值の大きい順に第 1 モード, 第 2 モードとした運動モードと呼ばれる特異值分解による主成分分析の 結果としては第 1 主成分, 第2 主成分を指寸, 運動計測データ全体としての観測行列における主成分べクトルで表される 主要な運動パターンである各正規直交基底ベクトルの寄与度であり, $v_{j}(t)$ は各基底の活動パターン, $\mathbf{z}_{j}(\bar{\theta}, \bar{M})$ は 各基底における物理量の協調パターンを表し，それぞれ時間基底，空間基底と呼ぶ。すなわち，これらについて は，前者は運動に対して入力として生じた各物理量の挙動において全体の時系列パターンとしてどのように生じ ていたか, 後者は運動の結果としての出力といえる各物理量が運動全体に対して相互にどの程度寄与していたか, という物理現象を数值的に表したものである.さらに，観測されたすべての運動モードに対する $j$ 番目の特異値 $\lambda_{j}$ が持つ寄与率 $\gamma_{j}$ は以下の式で表すことができる.これは, 各運動モードが全体の運動に対してどの程度大き く寄与しているかを示すものである，本研究では，この寄与率を割合表示して大きい順に考慮するものとする.

$$
\gamma_{j}=\lambda_{j}^{2} / \sum_{j=1}^{n} \lambda_{j}^{2}
$$

\section{3. 実験方法}

\section{$3 \cdot 1$ 被験者および実験装置}

本研究では, 健常者であり標準的な体格を持つ成人男性 1 名および 20 年以上に渡って一般的なソケット型大腿 義足を装着している男性の右脚大腿切断者 1 名を被験者とする. ここで, 被験者を各 1 名とした理由としては, 本研究では, ヒトの歩行における下肢関節回転運動について, あくまでも関節角度に加えて関節モーメントの双 方を同時に考慮した新しい定量的な解析手法の提案とその適用例を示すことを目的としており, 適用した結果と して導き出される普遍的なヒトの歩行に現れる特徵に関してまでは言及せず，例として後述するトレッドミルを 用いた計測実験の結果に適用した場合の被験者として健常者と大腿義足装着者を代表的に示したこととする. 歩 行計測実験は同志社大学京田辺校地にて実施し，全体的な作業については臨床実験に関する同志社大学研究倫理 委員会の承認を得るとともに，あらかじめ被験者に十分な説明を与え，同意を得た. 計測前には約 20 分間の歩行 訓練を実施し, 装着した大腿義足の機能を十分に発揮した形での歩行が実現可能となった後に計測を開始する.

実験装置としては，テック技販社製のウェアラブルな歩行解析システムおよび左右分離式トレッドミルを用い る. 前者は，図 1 のようなシステム全体の構成図に示すように，片脚に 2 基ずつ合計 4 基の小型床反力計を靴底 に組み込んだサンダル型の移動式床反力計 1 足分に加えて, 片脚について 3 基ずつ組み込んだ合計 6 基の姿勢セ ンサおよびデータロガによって構成される. 小型床反力計の構造および各姿勢センサのセンサ座標系の名称をそ れぞれ図 2 , 図 3 に示寸. 図 2 に示寸ように, 小型床反力計は 2 枚の基板に 4 基のテック技販社製薄型 3 軸力覚 センサ USL06-H5-500N-C が挟まれた構造となっている. 小型床反力計, 姿勢センサならびにデータロガはいず れも比較的軽量かつ装着者への負担が少なく, 使用しやすいものとなっている. 姿勢センサには STM 社製 3 軸 加速度センサ LIS331DLH, STM 社製 2 軸ジャイロセンサ LPR530AL および STM 社製 1 軸ジャイロセンサ LY530ALH から構成される 3 軸ジャイロセンサ, Honeywell 社製 3 軸地磁気センサ HMC5843 が内蔵されており, 
Hayashi, Tsujiuchi, Nakamura, Makino, Asano, Matsuda and Tsuchiya,

Transactions of the JSME (in Japanese), Vol.82, No.834 (2016)

大腿部，下腿部，腰部，背部に装着することによって下肢および体幹の運動学情報を計測する．各種センサの仕 様を表 1 に示寸. 小型床反力計には, 姿勢センサと同様に加速度センサ, ジャイロセンサ, 地磁気センサが内蔵 されており，足の運動学情報を計測する．移動式床反力計および姿勢センサにおいて計測されたデータはデータ ロガを介して無線 LAN により PC に転送・記録され，それらを演算することにより歩行運動時における床反力 および下肢の姿勢を表す関節角度, 関節モーメントを算出可能である.

また，後者であるトレッドミルを図４に示す，本装置は左右のベルトが独立しているため各ベルトの運転は同 期および非同期の切り替えが可能となっており，それぞれの正転・逆転およびベルト速度が指定可能である。な お, ベルトの最大速度は $30[\mathrm{~km} / \mathrm{h}]$, 最大分解能は $0.1[\mathrm{~km} / \mathrm{h}]$ である. ここで, 先行研究として, 地上とトレッドミ ル上の歩行は運動学および動力学的な観点から類似しているという旨の報告がなされている(Riley et al., 2007)こ とから, 本研究においてはトレッドミル上の歩行を地上歩行と同等とみなし, 以下の解析をおこなうものとする.

\section{$3 \cdot 2$ 実験条件}

トレッドミル上において，図 5 および図 6 に示すようにウェアラブルな歩行解析システム一式を装着した健常 者および大腿義足装着者が左右のベルトを同期し, ベルト速度 $1 ， 2 ， 3[\mathrm{~km} / \mathrm{h}]$ の条件で 30[s]歩行をおこなった際 の計測データを取得する，ここで，歩行解析システム装着時における移動式床反力計，姿勢センサならびにデー タロガの位置を図 7 に示寸．また， ウェアラブルな歩行解析システムに組み込んだセンサについて設定した各種 条件として, 地磁気センサ以外については各 chにおけるサンプリング周波数を $100[\mathrm{~Hz}]$ とするとともに，ローパ スフィルタのカットオフ周波数を $10[\mathrm{~Hz}]$ とし，地磁気センサについてはサンプリング周波数を $10[\mathrm{~Hz}]$, カット オフ周波数を $5[\mathrm{~Hz}]$ とする. データ解析においては, 各歩行条件においてそれぞれ計測した一歩行周期中に生じ る床反力, 関節角度, 関節モーメントを考慮する。 ここで, 一歩行周期は踵が接地してから再び接地するまでの 立脚期から遊脚期にわたる時間と定義し, 立脚期と遊脚期との間における遷移点を床反力の垂直方向成分 $F_{z}$ の曲 線から判断する．さらに，各歩行条件について正規化をおこなうため，一歩行周期の全時間を 100 [\%]とする.

\section{$3 \cdot 3$ データ解析手順}

前節の歩行計測実験に関するデータ解析として, 使用したウェアラブルな計測装置における各種出力を演算処 理することにより，反モーメントを含めた床反力，関節角度ならびに関節モーメントの算出が可能となる.

最初に, 移動式床反力計に組み込んだ小型床反力計の出力である床反力について述べる. 小型床反力計の出力 に関して, 爪先側を添字の toe, 踵側を添字の heel で表し, 移動式床反力計における片足全体の座標原点を踵側

の小型床反力計における座標原点と一致するように定義した場合, 片足全体の床反力 $\boldsymbol{F}=\left(F_{x} F_{y} F_{z}\right)^{T}$, 反モー メント $\boldsymbol{M}=\left(M_{x} M_{y} M_{z}\right)^{T}$ は以下の式で表される.

$$
\begin{aligned}
& \boldsymbol{F}=\left(\begin{array}{l}
F_{x} \\
F_{y} \\
F_{z}
\end{array}\right)=\left(\begin{array}{l}
F_{x t o e}^{\prime}+F_{x h e e l}^{\prime} \\
F_{y_{\text {toe }}}^{\prime}+F_{y_{\text {heel }}}^{\prime} \\
F_{\text {ztoe }}^{\prime}+F_{z \text { zheel }}^{\prime}
\end{array}\right) \\
& \boldsymbol{M}=\left(\begin{array}{l}
M_{x} \\
M_{y} \\
M_{z}
\end{array}\right)=\left(\begin{array}{l}
M_{\text {xtoe }}^{\prime}+M_{\text {xheel }}^{\prime}+F_{z \text { toe }}^{\prime} d \\
M_{y_{\text {toe }}}^{\prime}+M_{y_{\text {heel }}}^{\prime} \\
M_{\text {ztoe }}^{\prime}+M_{\text {zheel }}^{\prime}-F_{x \text { toe }}^{\prime} d
\end{array}\right)
\end{aligned}
$$

ここで, $d$ は 2 基の小型床反力計における座標原点間の距離であり,$d=0.15[\mathrm{~m}]$ である.

次に, 姿勢センサの出力から求められる関節角度, 関節モーメントについて述べる. 姿勢センサに組み込んだ 加速度センサの出力である各軸方向の加速度 $a_{x}, a_{y}, a_{z}$ を用いて, $x$ 軸周りの関節角度 $\theta_{x}$ を次式により算出する.

$$
\theta_{x}=-\tan ^{-1} \frac{a_{y}}{\sqrt{a_{x}^{2}+a_{z}^{2}}}
$$


また， $y$ 軸周りの関節角度 $\theta_{y}$ は以下のように場合分けして算出する.

$$
\theta_{y}= \begin{cases}-\tan ^{-1}\left(\frac{a_{x}}{a_{z}}\right) & \text { if } a_{x} \neq 0 \text { and } a_{z} \leq 0 \\ -\tan ^{-1}\left(\frac{a_{x}}{a_{z}}\right)+\pi & \text { if } a_{x}>0 \text { and } a_{z}>0 \\ -\tan ^{-1}\left(\frac{a_{x}}{a_{z}}\right)-\pi & \text { if } a_{x}<0 \text { and } a_{z}>0\end{cases}
$$

さらに, $z$ 軸周りの関節角度 $\theta_{z}$ についても以下のように場合分けして算出する。ここで，姿勢センサに組み込ん だ地磁気センサの各軸方向出力をそれぞれ $c_{x}, c_{y}, c_{z}$ とする.

$$
\theta_{z}= \begin{cases}\tan ^{-1}\left(\frac{c_{x}}{c_{y}}\right) & \text { if } c_{y} \geq 0 \\ \frac{\pi}{2} & \text { if } c_{x}>0 \text { and } c_{y}=0 \\ -\frac{\pi}{2} & \text { if } c_{x}<0 \text { and } c_{y}=0 \\ \tan ^{-1}\left(\frac{c_{x}}{c_{y}}\right)+\pi & \text { if } c_{x}>0 \text { and } c_{y}<0 \\ \tan ^{-1}\left(\frac{c_{x}}{c_{y}}\right)-\pi & \text { if } c_{x}<0 \text { and } c_{y}<0\end{cases}
$$

各関節モーメントについて考えると, 足関節に生じる $x, y, z$ 軸周りのモーメント $M_{x_{\text {ankle }}}, M_{y_{\text {ankle }}}, M_{\text {zankle }}$ はそ れぞれ次式で求められる。 ここで, 以下の式を用いた関節モーメントの導出に関しておこなった, 本研究におけ るヒトの歩行時についての下肢姿勢のモデル化として, 足, 膝, 股関節ならびに小型床反力計における中心位置 座標 $\boldsymbol{O}=\left(\begin{array}{lll}O_{x} & O_{y} & O_{z}\end{array}\right)^{T}$, 関節間ベクトルを $\boldsymbol{L}=\left(\begin{array}{lll}L_{x} & L_{y} & L_{z}\end{array}\right)^{T}$ とおいた場合, 本システムを装着した際に定義 される下肢モデルを図 8 に示す. ${ }^{S} X,{ }^{S} Y,{ }^{S} Z$ はセンサ座標系である. さらに, 歩行時の下肢モデルにおける仮定 は（1）必ず4 基の小型床反力計の内いずれかで立脚している，(2) 立脚している小型床反力計の中心位置座標は 変化しない，（3）Lの大きさは変化しない，（4）各センサは脚部に固定されているため，Lはセンサ座標系とと もに回転する，の 4 通りとした. 加えて，モデルにおける Free Body Diagram の一部として足関節および足部のつ ま先, 踵に関するものを図 9 に示す. 図 9 の各距離などそれぞれのパラメータについては後述することとする.

$$
\begin{aligned}
& M_{\text {xankle }}=l_{y 1} F_{z \text { toe }}^{\prime}-l_{z 1} F_{y \text { toe }}^{\prime}+l_{y 4} F_{z \text { heel }}^{\prime}-l_{z 4} F_{y \text { heel }}^{\prime}-l_{y 7} m_{\text {foot }} g+M_{x \text { toe }}^{\prime}+M_{x h e e l}^{\prime}+\left\{m_{\text {foot }}\left(l_{y 7}{ }^{2}+l_{z 7}{ }^{2}\right)+I_{x 1} \ddot{\theta}_{x 1}\right. \\
& M_{y_{\text {ankle }}}=l_{z 1} F_{x \text { toe }}^{\prime}-l_{x 1} F_{z \text { toe }}^{\prime}+l_{z 4} F_{x h e e l}^{\prime}-l_{x 4} F_{z h e e l}^{\prime}+l_{x 7} m_{\text {foot }} g+M_{y_{\text {toe }}}^{\prime}+M_{y_{\text {heel }}}^{\prime}+\left\{m_{\text {foot }}\left(l_{x 7}{ }^{2}+l_{z 7}{ }^{2}\right)+I_{y 1} \ddot{\theta}_{y 1}\right. \\
& M_{\text {zankle }}=l_{x 1} F_{y_{\text {toe }}}^{\prime}-l_{y 1} F_{x \text { toe }}^{\prime}+l_{x 4} F_{y_{\text {heel }}}^{\prime}-l_{y 4} F_{x \text { heel }}^{\prime}+M_{z \text { toe }}^{\prime}+M_{z \text { heel }}^{\prime}+\left\{m_{\text {foot }}\left(l_{x 7}{ }^{2}+l_{y 7}{ }^{2}\right)+I_{z 1}\right\} \ddot{\theta}_{z 1}
\end{aligned}
$$

また, 膝関節に生じる $x, y, z$ 軸周りのモーメント $M_{x k n e e}, M_{y_{k n e e}}, M_{z k n e e}$ は次式で求められる.

$$
\begin{aligned}
M_{x \text { knee }}= & l_{y 2} F_{z \text { toe }}^{\prime}-l_{z 2} F_{y_{\text {toe }}}^{\prime}+l_{y 5} F_{\text {zheel }}^{\prime}-l_{z 5} F_{y \text { heel }}^{\prime}-\left(l_{y 8} m_{\text {foot }}+l_{y 9} m_{\text {shank }}\right) g \\
& +M_{x \text { toe }}^{\prime}+M_{x \text { heel }}^{\prime}+\left\{m_{\text {foot }}\left(l_{y 8}{ }^{2}+l_{z 8}{ }^{2}\right)+I_{x 1} \ddot{\theta}_{x 1}+\left\{m_{\text {shank }}\left(l_{y 9}{ }^{2}+l_{z 9}{ }^{2}\right)+I_{x 2}\right\} \ddot{\theta}_{x 2}\right. \\
M_{y_{\text {knee }}=} & l_{z 2} F_{x \text { toe }}^{\prime}-l_{x 2} F_{\text {ztoe }}^{\prime}+l_{z 5} F_{x \text { heel }}^{\prime}-l_{x 5} F_{z \text { heel }}^{\prime}+\left(l_{x 8} m_{\text {foot }}+l_{x 9} m_{\text {shank }}\right) g \\
& +M_{y_{\text {toe }}}^{\prime}+M_{y_{\text {heel }}}^{\prime}+\left\{m_{\text {foot }}\left(l_{x 8}{ }^{2}+l_{z 8}{ }^{2}\right)+I_{y 1} \ddot{\theta}_{y 1}+\left\{m_{\text {shank }}\left(l_{x 9}{ }^{2}+l_{z 9}{ }^{2}\right)+I_{y 2}\right\} \ddot{\theta}_{y 2}\right.
\end{aligned}
$$




$$
\begin{aligned}
M_{z \text { knee }}= & l_{x 2} F_{y \text { toe }}^{\prime}-l_{y 2} F_{x \text { toe }}^{\prime}+l_{x 5} F_{y \text { heel }}^{\prime}-l_{y 5} F_{\text {xheel }}^{\prime}+M_{z \text { toe }}^{\prime}+M_{z \text { heel }}^{\prime} \\
& +\left\{m_{\text {foot }}\left(l_{x 8}{ }^{2}+l_{y 8}{ }^{2}\right)+I_{z 1}\right\}_{z 1}+\left\{m_{\text {shank }}\left(l_{x 9}{ }^{2}+l_{y 9}{ }^{2}\right)+I_{z 2}\right\} \ddot{\theta}_{z 2}
\end{aligned}
$$

さらに, 股関節に生じる $x, y, z$ 軸周りのモーメント $M_{x h i p}, M_{y_{h i p}}, M_{z h i p}$ は次式で求められる.

$$
\begin{aligned}
M_{x h i p}= & l_{y 3} F_{z \text { toe }}^{\prime}-l_{z 3} F_{y_{\text {toe }}}^{\prime}+l_{y 6} F_{z \text { heel }}^{\prime}-l_{z 6} F_{y \text { heel }}^{\prime}-\left(l_{y 10} m_{\text {foot }}+l_{y 11} m_{\text {shank }}+l_{y 12} m_{\text {thigh }}\right) g+M_{x \text { toe }}^{\prime}+M_{x h \text { hel }}^{\prime} \\
& +\left\{m_{\text {foot }}\left(l_{y 10}{ }^{2}+l_{z 10}{ }^{2}\right)+I_{x 1}\right\} \ddot{\theta}_{x 1}+\left\{m_{\text {shank }}\left(l_{y 11}{ }^{2}+l_{z 11}{ }^{2}\right)+I_{x 2}\right\} \ddot{\theta}_{x 2}+\left\{m_{\text {thigh }}\left(l_{y 12}{ }^{2}+l_{z 12}{ }^{2}\right)+I_{x 3}\right\} \ddot{\theta}_{x 3} \\
M_{y_{\text {hip }}}= & l_{z 3} F_{x \text { toe }}^{\prime}-l_{x 3} F_{z \text { toe }}^{\prime}+l_{z 6} F_{x h e e l}^{\prime}-l_{x 6} F_{z h e e l}^{\prime}+\left(l_{x 10} m_{\text {foot }}+l_{x 11} m_{\text {shank }}+l_{x 12} m_{\text {thigh }}\right) g+M_{y_{\text {toe }}}^{\prime}+M_{y_{\text {heel }}}^{\prime} \\
& +\left\{m_{\text {foot }}\left(l_{x 10}{ }^{2}+l_{z 10}{ }^{2}\right)+I_{y 1}\right\} \ddot{\theta}_{y 1}+\left\{m_{\text {shank }}\left(l_{x 11}{ }^{2}+l_{z 11}{ }^{2}\right)+I_{y 2}\right\} \ddot{\theta}_{y 2}+\left\{m_{\text {thigh }}\left(l_{x 12}{ }^{2}+l_{z 12}{ }^{2}\right)+I_{y 3} \ddot{\theta}_{y 3}\right. \\
M_{z h i p}= & l_{x 3} F_{y \text { toe }}^{\prime}-l_{y 3} F_{x t o e}^{\prime}+l_{x 6} F_{y \text { heel }}^{\prime}-l_{y 6} F_{x h e l l}^{\prime}+M_{z t o e}^{\prime}+M_{z h e e l}^{\prime} \\
& +\left\{m_{\text {foot }}\left(l_{x 10}{ }^{2}+l_{y 10}{ }^{2}\right)+I_{z 1}\right\} \ddot{\theta}_{z 1}+\left\{m_{\text {shank }}\left(l_{x 11}{ }^{2}+l_{y 11}{ }^{2}\right)+I_{z 2}\right\} \ddot{\theta}_{z 2}+\left\{m_{\text {thigh }}\left(l_{x 12}{ }^{2}+l_{y 12}{ }^{2}\right)+I_{z 3}\right\} \ddot{\theta}_{z 3}
\end{aligned}
$$

ここで, $g$ は重力加速度, $m_{\text {foot }}, m_{\text {shank }}, m_{\text {thigh }}$ は独立行政法人産業技術総合研究所デジタルヒューマン工学センタ 一の「慣性特性データベース」において公開されている人体特性(Zatsiorsky, 1983)から得られた足部，下腿部，大

腿部の質量, $\ddot{\theta}_{x j}, \ddot{\theta}_{y j}, \ddot{\theta}_{z j}(j=1,2,3)$ は姿勢センサに組み込んだジャイロセンサの出力を微分して得られた足, 膝, 股関節の $x, y, z$ 軸周りに生じる角加速度, $I_{x j}, I_{y j}, I_{z j}(j=1,2,3)$ は人体特性(Zatsiorsky, 1983)から得られた足部, 下腿部，大腿部の慣性モーメント， $l_{x 1}, \ldots, l_{x 12}, l_{y 1}, \ldots, l_{y 12}, l_{z 1}, \ldots, l_{z 12}$ は順に計測した足，膝，股関節からつま先側 の小型床反力計における座標原点までの $x$ 軸方向距離, 足, 膝, 股関節から足底圧中心点までの $x$ 軸方向距離, 足関節から足部の質量中心点までの $x$ 軸方向距離，膝関節から足部および下腿部の質量中心点までの $x$ 軸方向距 離，股関節から足部，下腿部，大腿部の質量中心点までの $x$ 軸方向距離，足，膝，股関節からつま先側の小型床 反力計における座標原点までの $y$ 軸方向距離，足，膝，股関節から足底圧中心点までの $y$ 軸方向距離，足関節か ら足部の質量中心点までの $y$ 軸方向距離，膝関節から足部および下腿部の質量中心点までの $y$ 軸方向距離，股関 節から足部, 下腿部, 大腿部の質量中心点までの $y$ 軸方向距離, 足, 膝, 股関節からつま先側の小型床反力計に おける座標原点までの $z$ 軸方向距離, 足, 膝, 股関節から足底圧中心点までの $z$ 軸方向距離, 足関節から足部の 質量中心点までの $z$ 軸方向距離, 膝関節から足部および下腿部の質量中心点までの $z$ 軸方向距離, 股関節から足 部，下腿部，大腿部の質量中心点までの $z$ 軸方向距離を表し，これらは正負の值をとるものとする.

なお，システム全体の座標系については両脚ともに右手座標系に対応させ，関節角度や関節モーメントの各軸 周り回転方向は図 10 に示すように右ねじの方向を正とする.健常者の歩行運動に関しては左右対称であると考え られるため，大腿義足装着者の健足側と比較寸ることを考慮して左脚の結果のみを用いる．大腿義足装着者の関 節モーメントに関しては義足側では人体特性によるデータを用いることができないため，健足側に関してのみ算 出する．データ解析においては，左右の脚それぞれの立脚期と遊脚期との間における遷移点の関係性から，一歩 行周期を両脚支持期 1 (DSP1), 片脚支持期（SSP），両脚支持期 2 (DSP2), 遊脚期（SWP）の順に 4 種類のフェ ーズに分割する.

Table 1 Specification of various sensors in the wearable gait motion analysis system. They have satisfactory accuracies.

\begin{tabular}{c|c|c|c}
\hline \hline & Rated Value & Nonlinearity & Responsive \\
\hline Force Sensor & $\begin{array}{c}\mathrm{XY}: \pm 250[\mathrm{~N}] \\
\mathrm{Z}: \pm 500[\mathrm{~N}]\end{array}$ & $\pm 1[\% \mathrm{FS}]$ & $2[\mathrm{kHz}]$ \\
\hline Acceleration Sensor & $\pm 19.6\left[\mathrm{~m} / \mathrm{s}^{2}\right]$ & $\pm 1[\% \mathrm{FS}]$ & $500[\mathrm{~Hz}]$ \\
\hline Gyro Sensor & $\pm 1200[\mathrm{deg} / \mathrm{s}]$ & $\pm 1[\% \mathrm{FS}]$ & $140[\mathrm{~Hz}]$ \\
\hline Geomagnetic Sensor & $\pm 70000[\mathrm{nT}]$ & $\pm 0.1[\% \mathrm{FS}]$ & $10[\mathrm{~Hz}]$ \\
\hline
\end{tabular}

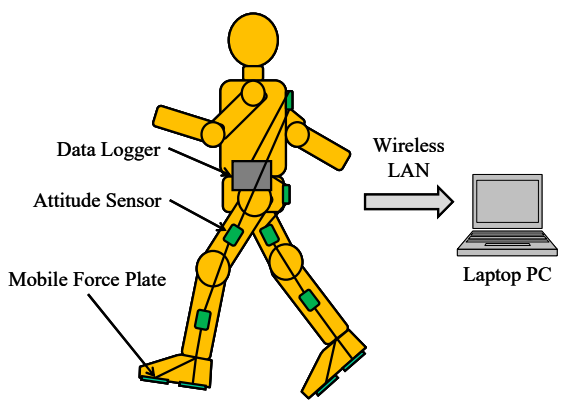

Fig. 1 Wearable gait motion analysis system. This system includes mobile force plate and attitude sensor. 


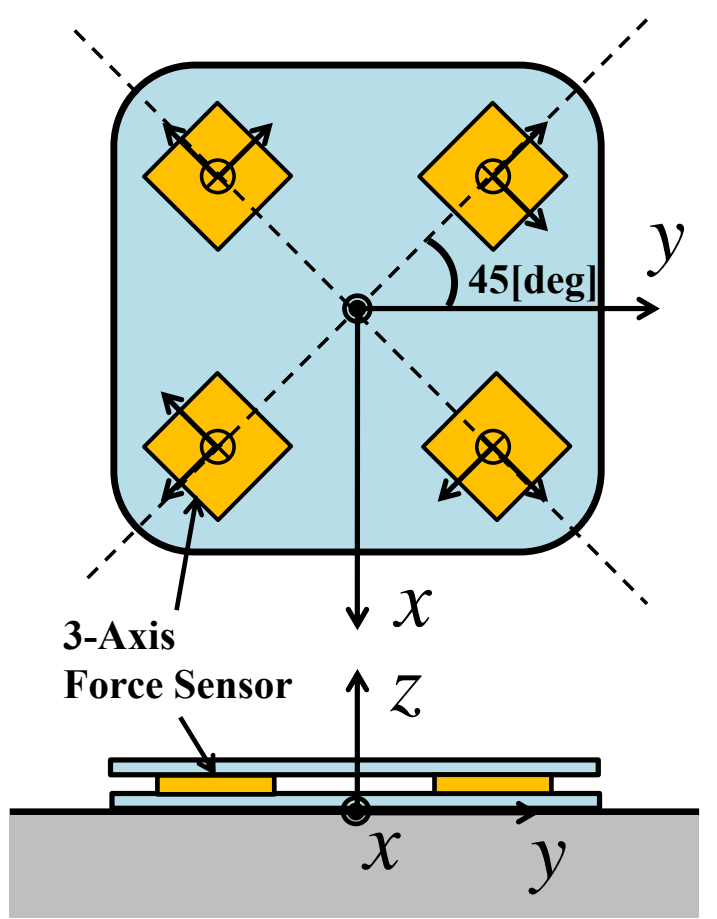

Fig. 2 Internal constitution of mobile force plate. 3-axis force sensors are sandwiched in between two plates.

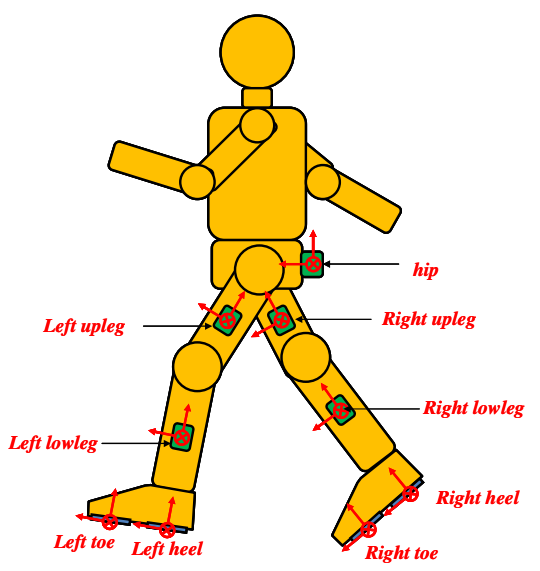

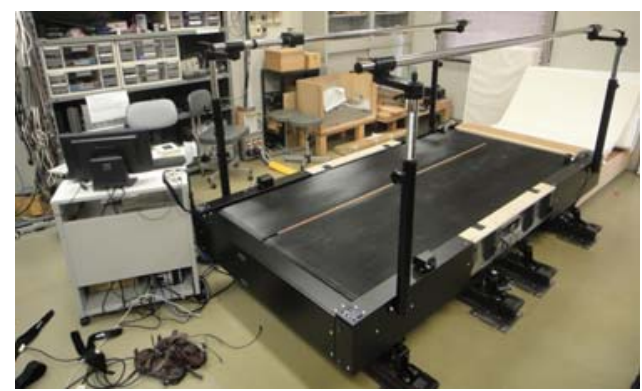

Fig. 4 Split-belt treadmill. Handrails and mat are installed for safety.

Fig. 3 Names of sensor coordinate systems.

These attitude sensors have fixed coordinate systems.

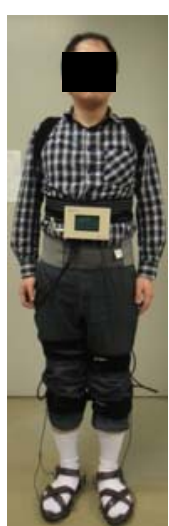

(a) Front

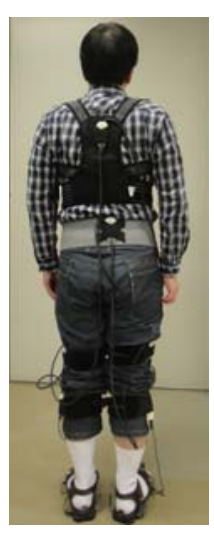

(b) Back

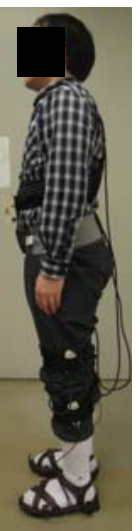

(c) Left side

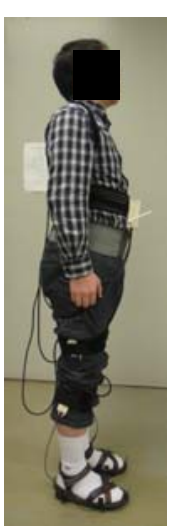

(d) Right side

Fig. 5 Healthy subject with wearable gait analysis system. Attitude sensors are easy to wear by dedicated belt.

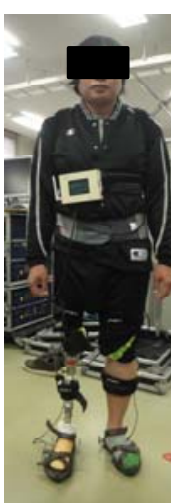

(a) Front

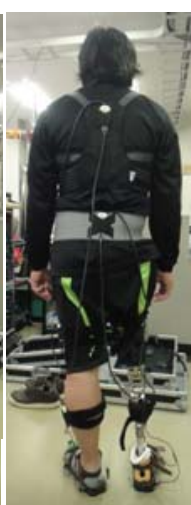

(b) Back

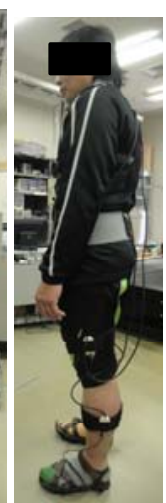

(c) Left side

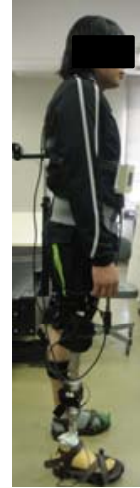

(d) Right side
Fig. 6 Trans-femoral amputee with wearable gait analysis system. Sound limb and prosthetic limb are symmetrically worn. 


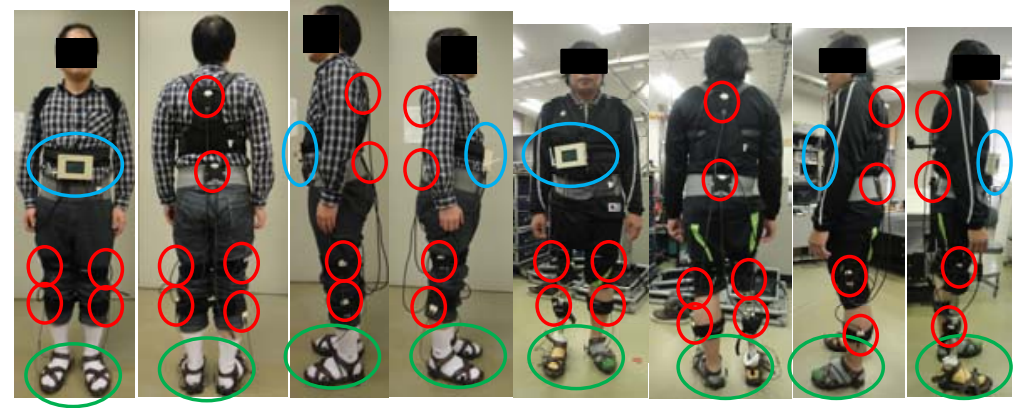

- Mobile Force Plate - Attitude Sensor - Data Logger

Fig. 7 Positions of each sensor system and data logger. Green, red and light blue circles indicate mobile force plate, attitude sensor and data logger.
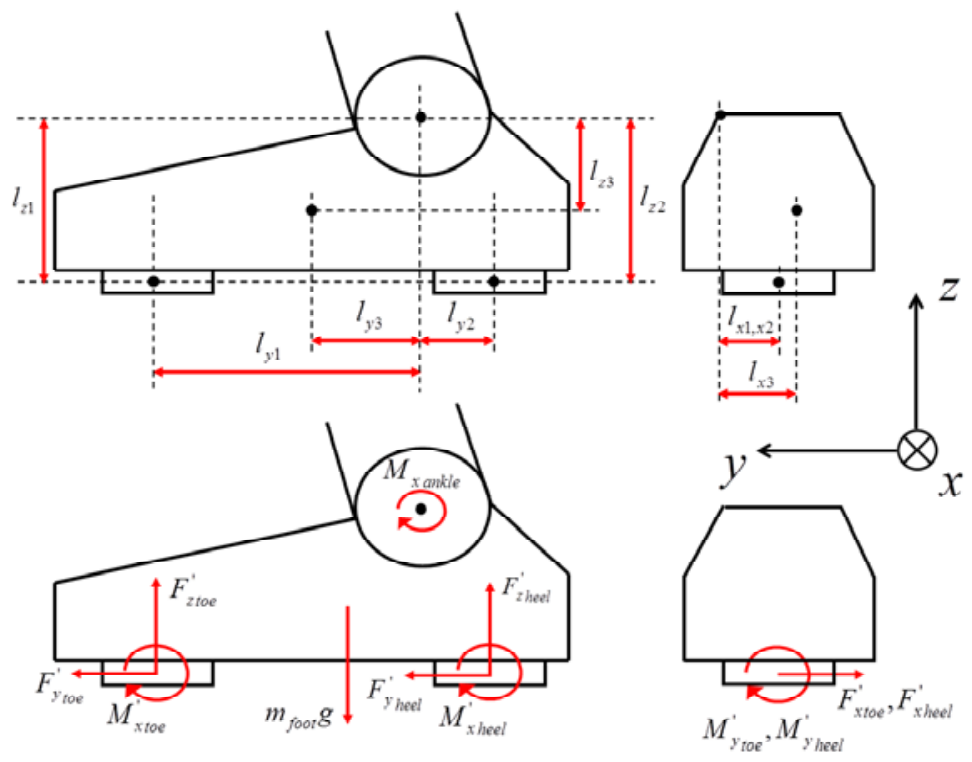

Fig. 9 Free body diagram of ankle joint and foot in the lower leg model. Left figure and right figure indicate side and back surfaces.

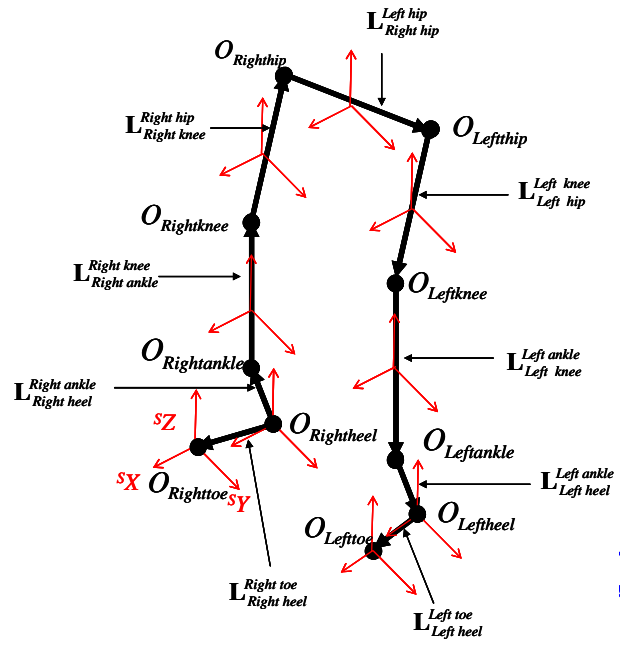

Fig. 8 Lower leg model. This model is assumed by sensor coordinate systems.

\section{4. 実験結果および考察}

本章では，前章で述べた移動式床反力計，姿勢センサおよびデータロガから構成されるウェアラブルな歩行解 析システムを用いた実験結果から，各ベルト速度において両脚支持期 1 （DSP1），片脚支持期（SSP），両脚支持 期 2 （DSP2），遊却期（SWP）のフェーズごとに関節角度および関節モーメントを算出し，これらで構成される 観測行列について特異值分解を施す，それにより, 歩行運動の関節間協調動作の中でも相関が高い動作パターン を抽出し，大腿義足装着者の歩行を健常者と比較考察し，定量的に解析ならびに評価することによって，本研究 における提案手法の有効性を検証する，なお，以下では空間基底における関節角度および関節モーメントの正負 とそれらに対応寸る身体の解剖学的な運動方向について, 図 10 に示したように正の方向を定義する. 具体的には, 足関節では図 10 における右対じの方向を正の方向とみなし，背屈を正，底屈を負というように定義し，膝・股関 節では足関節の場合と同様の理由から，それぞれ伸展を正，屈曲を負と定義し，屈曲を正，伸展を負と定義する.

\section{$4 \cdot 1$ 寄与率}

算出した関節角度および関節モーメントに関して，各ベルト速度の各フェーズ（両脚支持期 1（DSP1），片脚 支持期（SSP），両脚支持期 2（DSP2），遊脚期（SWP） ごとに，これらで構成される観測行列について特異值分 解を施し, 歩行運動の関節間協調動作の中でも相関が高い動作パターンを抽出した. 結果の一例を以下に示す.

健常者および大腿義足装着者の各ベルト速度 $1,2,3[\mathrm{~km} / \mathrm{h}]$ での歩行において各フェーズの第 1 および第 2 モー ドの寄与率をそれぞれ図 11 および図 12 に示す。ここで，各運動モードの寄与率が高ければ，寄与率の分だけそ 
Hayashi, Tsujiuchi, Nakamura, Makino, Asano, Matsuda and Tsuchiya,

Transactions of the JSME (in Japanese), Vol.82, No.834 (2016)

の運動モードが全体の運動に対して割合を占め，運動モードにおける空間基底などのパターンによって運動全体 をその割合分表現できることを示している．図 11 および図 12 より，両被験者ともに全フェーズにおいて第 2 モ 一ドまでの累積寄与率が $80[\%]$ を超えていることが読み取れる．これは，大腿義足装着者の歩行運動は健常者と 同様に主に第 1 モードおよび第 2 モードで構成されていることを示している. ここで，特に寄与率の大きい第 1 モードについて着目寸ると，健常者については主に両脚支持期において速度が大きくなるにつれて寄与率も大き くなり, 片脚支持期および遊脚期において速度が大きくなるにつれて寄与率は小さくなるという傾向がみられた. これは，健常者はベルト速度の増大につれて運動が激しくなりシンプルでない複雑な動作パターンとなっている が，両脚支持期は短くなるため逆に運動の程度が少なくなりシンプルとなっていることを表すと考えられる.

また，大腿義足装着者については，全フェーズにおいて $1[\mathrm{~km} / \mathrm{h}]$ から $2[\mathrm{~km} / \mathrm{h}]$ で寄与率は減少し， $2[\mathrm{~km} / \mathrm{h}]$ から $3[\mathrm{~km} / \mathrm{h}]$ では増加するという健常者の場合とは異なる傾向がみられた. $1[\mathrm{~km} / \mathrm{h}]$ という普段おこなわない極めて低速 での歩行を除外して考えると, 大腿義足装着者の歩行運動では $2[\mathrm{~km} / \mathrm{h}]$ での歩行よりも $3[\mathrm{~km} / \mathrm{h}]$ で歩行の方が運 動パターンとしてより自然でシンプルな動作であったと考えられる.

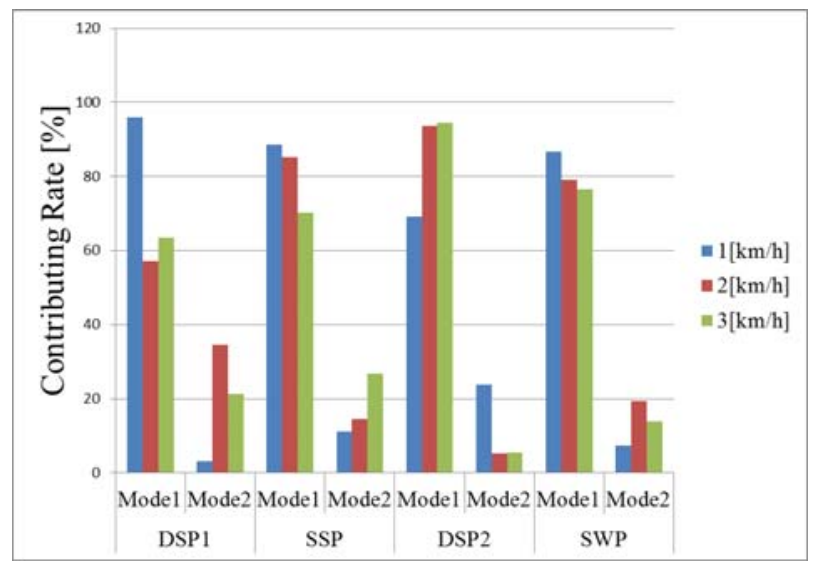

Fig. 11 Contributing rate of healthy subject. Velocity is arranged in order of 1,2 and $3[\mathrm{~km} / \mathrm{h}]$.

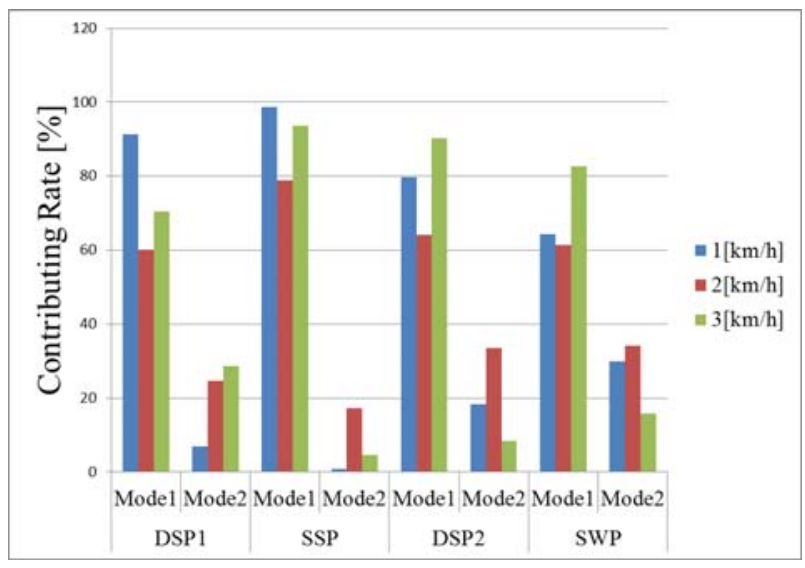

Fig. 12 Contributing rate of trans-femoral amputee. Velocity is arranged in order of 1,2 and $3[\mathrm{~km} / \mathrm{h}]$.

\section{$4 \cdot 2$ 空間基底}

前節より, 運動パターンとしてより自然でシンプルなベルト速度 $3[\mathrm{~km} / \mathrm{h}]$ で特に寄与率の大きい第 1 モードの空 間基底に関して, 健常者と大腿義足装着者の健足側について比較する. ベルト速度 $3[\mathrm{~km} / \mathrm{h}]$ のときの各フェーズに おける第 1 モードの空間基底を健常者について図 13〜図 16 に, 大腿義足装着者について図 17〜図 20 に示す. こ こで，空間基底とは第 2 章で触れたように，関節角度および関節モーメントといった物理量について単位や次元 の違いを排除するために值を標準化した時系列データの観測行列を特異值分解し，得られた正規直交基底べクト ルである特異べクトルにおける各物理量に対応する, -1 から 1 までの大きさで表される無次元量の主成分である. すなわち, 值が大きく $1,-1$ に近ければ, 物理量は運動全体の正または負の方向に大きく寄与しているといえる.

さらに，比較のため，結果の一例として，各被験者における一歩行周期分の $x$ 軸周りに生じる関節角度，関節 モーメントの時系列変化を, 立脚期と遊脚期を合わせた一歩行周期の時間を 100 [\%]として正規化した上で, 各関 節について図 21〜図 24 にそれぞれ示寸.ここで, $\theta_{x_{\text {ankle }}}, \theta_{x_{\text {knne }}}, \theta_{x_{\text {hip }}}$ は $x$ 軸周りにそれぞれ働く各関節角度である.

\section{$4 \cdot 2 \cdot 1$ 両脚支持期 1}

図 13 および図 17 において足関節角度に着目寸ると，健常者と比較して大腿義足装着者について值が小さいこ とがわかる．これは，大腿義足歩行では，義足側のみで全体重を支える不安定な状態を安定化すべく素早く健足 側を接地させるため直前の遊脚期が短く，足関節を十分に底屈させる前にこのフェーズに入り，その結果足関節 角度変化の值が小さくなったためであると考えられる。しかし, 図 21 および図 23 においては実際の足関節角度 の計測值は大腿義足装着者の方が健常者よりも大きく, このフェーズ中における值の変化も双方でほぼ変わらな いことから，空間基底においては，各物理量に対応寸る值の大小はその物理量自体の数值的な大小を示すのでは なく, フェーズ中における物理量の運動に対する寄与度を意味していると考えられる. すなわち, 健常者の場合 は大腿義足装着者の場合よりもこのフェーズ中における足関節運動の及ぼす影響度合いが大きいことを示してい 
Hayashi, Tsujiuchi, Nakamura, Makino, Asano, Matsuda and Tsuchiya, Transactions of the JSME (in Japanese), Vol.82, No.834 (2016)

ると考えられる．また，関節モーメントに関しては健常者と大腿義足装着者では大きな違いがみられる．この中 でも特に踵接地時に重要な膝関節モーメントに着目すると, 健常者の歩行では, 踵接地時の膝関節には床反力に よる伸展モーメントが働いているにも関わらず筋力により膝関節を屈曲させることで着地時の衝撃を和らげるよ うな踏み込みの動作をしているが，大腿義足装着者では不自然な形でこのフェーズに入るため膝関節には屈曲モ 一メントが働き，この現象によって膝関節を屈曲させていると考えられる. 図 22 および図 24 においては, 図 13 および図 17 と各関節モーメントの正負の対応としては一致した傾向となったが, 図 24 のように負の方向に対し て股関節モーメントが最も大きくなったことと空間基底の值の大きさは対応しなかったことから，この場合は值 の正負と相関の正負は一致する関係となったが，空間基底の絶対值としての大きさは時系列挙動における物理量 の大きさと対応する関係にはなく,これはあくまでも運動全体に対する相関の大きさを表していると考えられる.

\section{$4 \cdot 2 \cdot 2$ 片脚支持期}

図 14 および図 18 において関節角度に着目すると, 健常者と大腿義足装着者ではほとんど差異はみられない. 片脚支持期では関節の角度としては同様の動きをしており，接地した足の上を下肢が前方に移動しながら膝関節 は伸展していく，図 21 および図 23 からは，双方ともに足関節，膝関節では值の変化はさほど大きくないが，股 関節では双方で運動の方向が異なることがわかり，これらをまとめて考えると，空間基底からはフェーズ中にお ける各関節の運動が挙動として一致しない場合でも, それらの運動全体に対する寄与度は同等となっていること を読み取ることができるといえる，他方，関節モーメントに着目すると，健常者と大腿義足装着者では特に足関 節および膝関節に大きな違いが表れている．健常者の場合，ここで次のフェーズに向け右脚側に体重を移動させ ていくが，大腿義足装着者の歩行では右脚が不安定な義足であるため，体重移動が進めば進む程，地面を蹴り出 し推進力を得て加速寸ることは危険と判断され困難となる．ゆえに，大腿義足装着者は安定しているこのフェー ズから早めに蹴り出しの準備を始めるため, 図 14 および図 18 に示すような結果が得られたと考えられる. 図 22 および図 24 においては, 図 14 および図 18 と比較して值の正負がともに概ね対応していた上, 全体的に前項の結 果と比較すると大腿義足装着者の関節モーメントの大きさ以外は一致するような関係にあったことから，この場 合は空間基底で表される值の相関度合いと実際の值としての正負が比較的一致するような挙動，状態にあったこ とが読み取れるといえる.

\section{$4 \cdot 2 \cdot 3$ 両脚支持期 2}

図 15 および図 19 において関節角度に着目寸ると, 健常者と大腿義足装着者ではほとんど差異はみられない. これより, 両脚支持期 2 では関節の角度としては同様の動きをしていると考えられる. 図 21 および図 23 からは, 双方の比較において足関節と膝関節で相互に逆方向への大きな運動をおこなっており, 前項と同様に, 空間基底 の值から，物理量の運動全体に対する寄与度は双方の運動の大きさに依存しないといえる．他方，関節モーメン トに着目すると，片脚支持期と同様に健常者と大腿義足装着者では特に足関節および膝関節によって大きな違い がみられる.この差異については前項において述べた理由が影響したものと考えられる. 図 22 および図 24 にお いては，図 15 および図 19 と比較して值の正負や大きさは対応，一致した関係とはならなかったが，それぞれの 関節モーメントにおける増加ないし減少の度合いをみると, 空間基底における值の正負と概ね致した関係にあ ることから，この場合は物理量としての運動全体に対する相関の大きさに関節モーメントの值そのものの増加な いし減少の度合いが反映され，大きく影響を及ぼしていることが空間基底から読み取れるといえる.

\section{$4 \cdot 2 \cdot 4$ 遊脚期}

図 16 に示寸健常者の歩行における関節角度・モーメントに着目すると, 全関節の角度・モーメントともに進行 方向に向いており，これは後方に残された下肢全体を前方へと移動させ，持ち上げる動作が反映されていると考 えられる. 図 20 に示寸大腿義足装着者の関節角度・モーメントに着目すると, 健常者とほぼ同様の傾向がみられ るが，他方，股関節角度についてのみ大きく異なる結果が得られた．これは，遊脚期において大腿義足装着者は 義足が膝折れしないように義足の膝関節を伸展させたまま全体重を義足に乗せることになるため, 健足側の股関 節自体が持ち上がった状態で義足を回転軸にして腰をひねりながら左足を前方へと移動させ，腿上げ動作をほと んどおこなわずに脚を下ろすため, 大腿義足装着者の股関節モーメントは伸展方向を示したと考えられる. 図 21 および図 23 からは, 膝関節と股関節において逆方向に大きく運動していることがわかり, これまでと同様に, 空 
Hayashi, Tsujiuchi, Nakamura, Makino, Asano, Matsuda and Tsuchiya,

Transactions of the JSME (in Japanese), Vol.82, No.834 (2016)

間基底からは時系列データの挙動に依存しない,物理量の運動全体に対する相関の度合いがわかると考えられる. 図 22 および図 24 においては，大腿義足装着者の股関節モーメントを除いて全体的には值そのものは非常に小さ くなっており，空間基底としても双方において一致した值となっていることから，遊脚期中において各関節モ一 メントは值そのものの大小にかかわらず一定の役割を果たし，それらは健常者と大腿義足装着者，空間基底と時 系列データのそれぞれの双方において概敉等しい傾向が得られ，これまでをまとめると，空間基底からはヒトの 歩行において生じる包括的な運動の特徵を直観的に把握でき，評価指標として非常に重要であると考えられる.

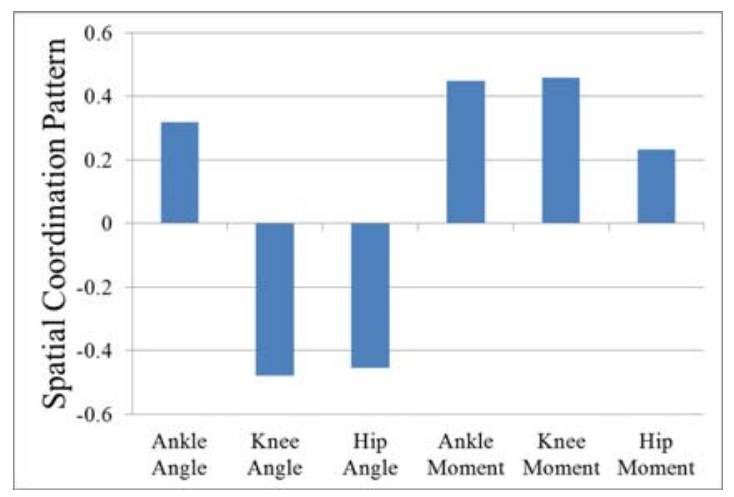

Fig. 13 Spatial coordination of mode 1 of double support phase 1 in healthy subject. Spatial coordination runs from -1 through 1.

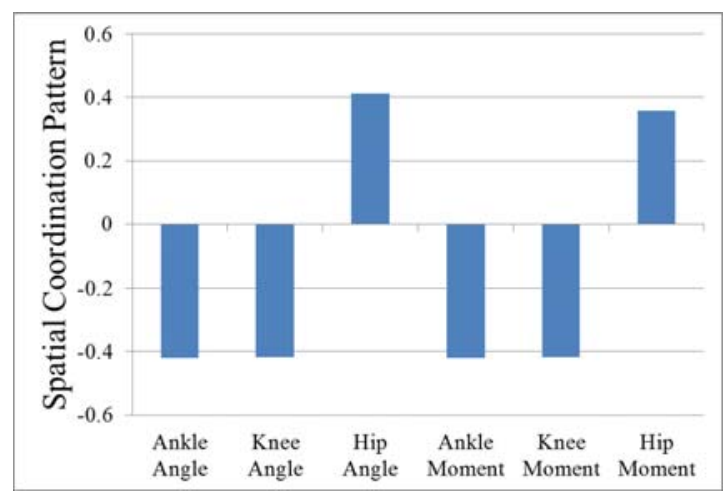

Fig. 15 Spatial coordination of mode 1 of double support phase 2 in healthy subject. Spatial coordination runs from -1 through 1 .

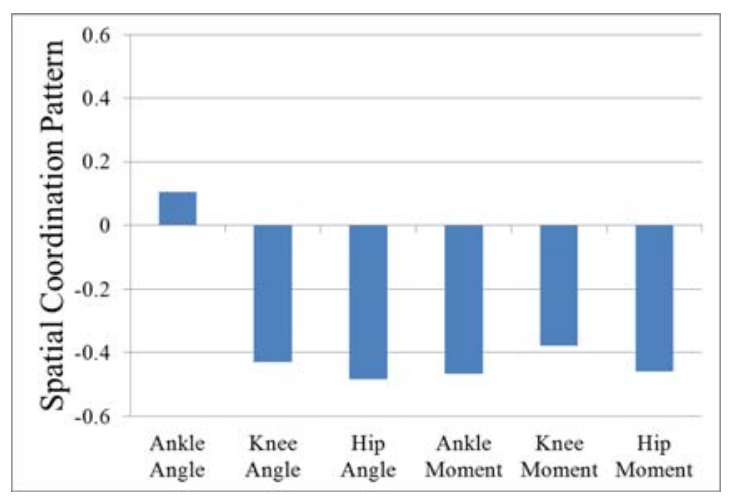

Fig. 17 Spatial coordination of mode 1 of double support phase 1 in trans-femoral amputee. Spatial coordination runs from -1 through 1 .

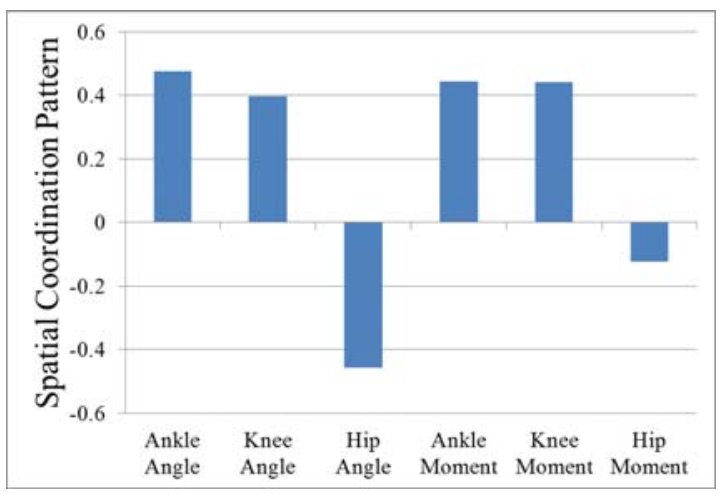

Fig. 14 Spatial coordination of mode 1 of single support phase in healthy subject. Spatial coordination runs from -1 through 1 .

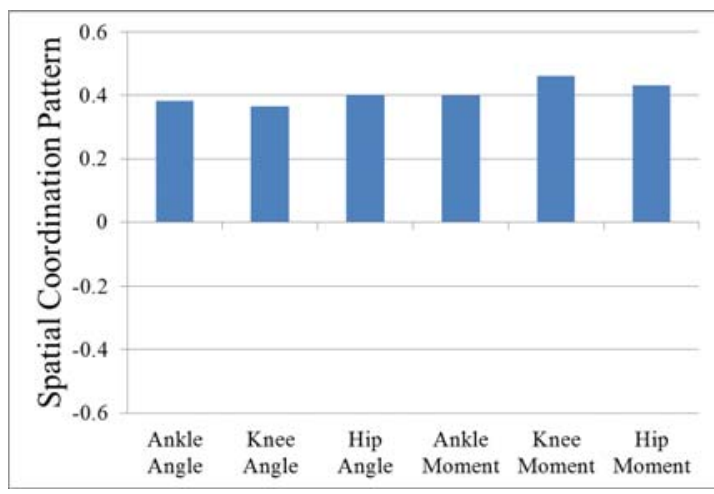

Fig. 16 Spatial coordination of mode 1 of swing phase in healthy subject. Spatial coordination runs from -1 through 1 .

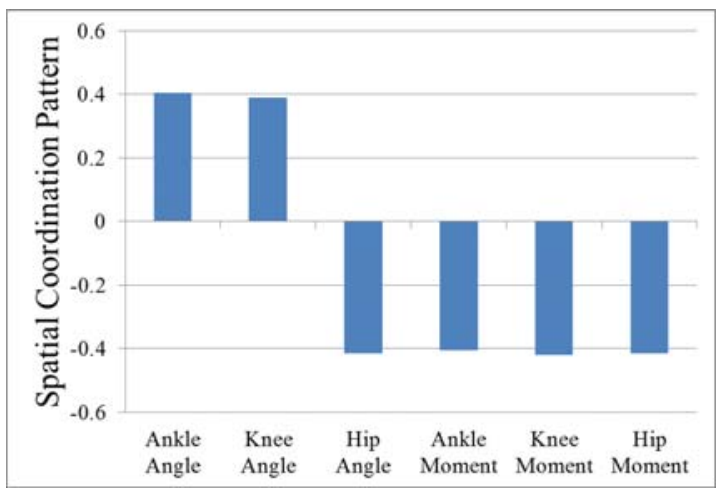

Fig. 18 Spatial coordination of mode 1 of single support phase in trans-femoral amputee. Spatial coordination runs from -1 through 1 . 


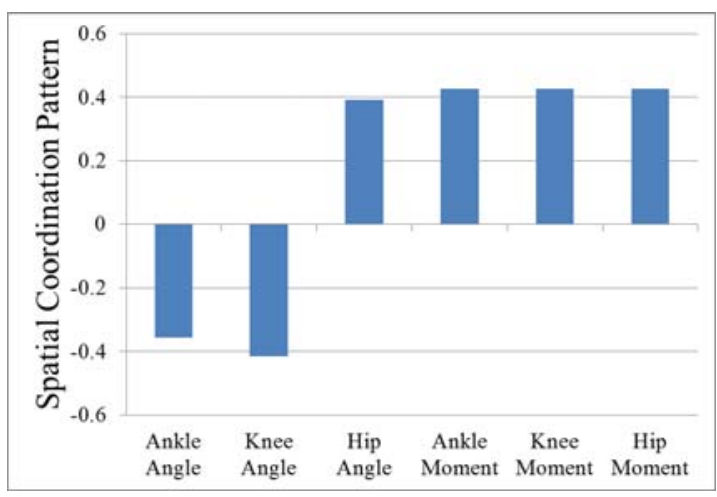

Fig. 19 Spatial coordination of mode 1 of double support phase 2 in trans-femoral amputee. Spatial coordination runs from -1 through 1 .

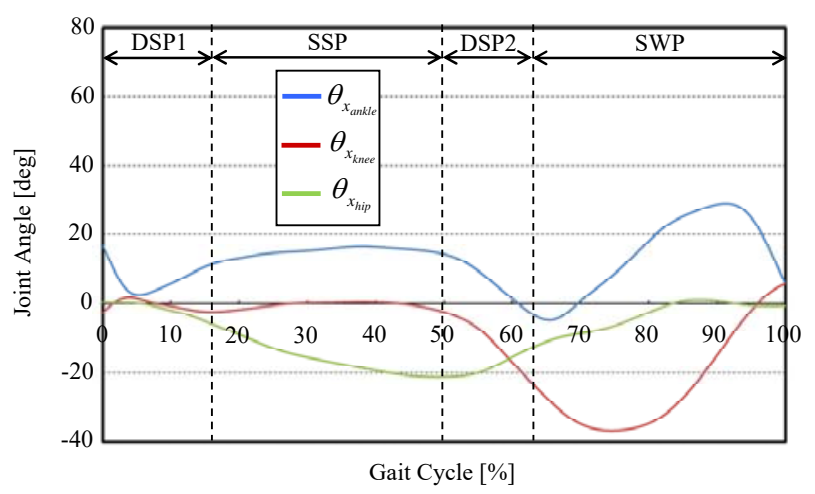

Fig. 21 Patterns of each joint angle in healthy subject. Gait cycle is divided into dsp1, ssp, dsp2 and swp.

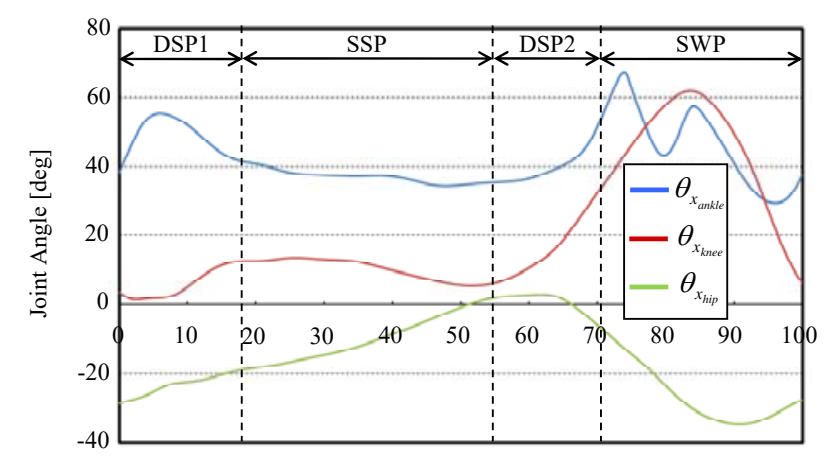

Gait Cycle [\%]

Fig. 23 Patterns of each joint angle in trans-femoral amputee. Gait cycle is divided into dsp1, ssp, dsp2 and swp.

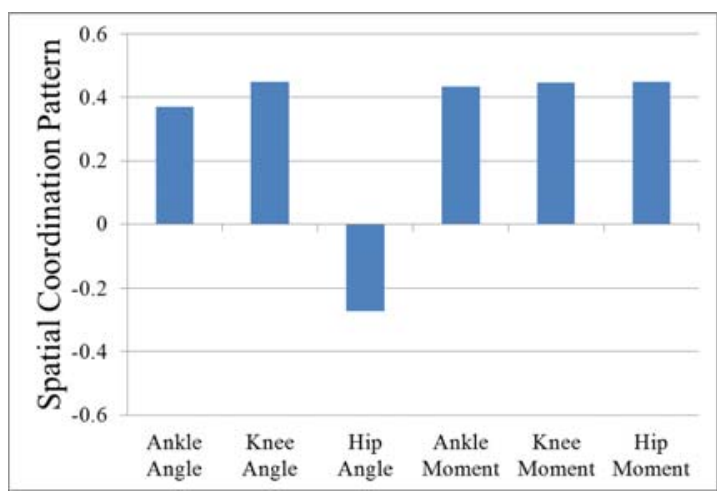

Fig. 20 Spatial coordination of mode 1 of swing phase in trans-femoral amputee. Spatial coordination runs from -1 through 1 .

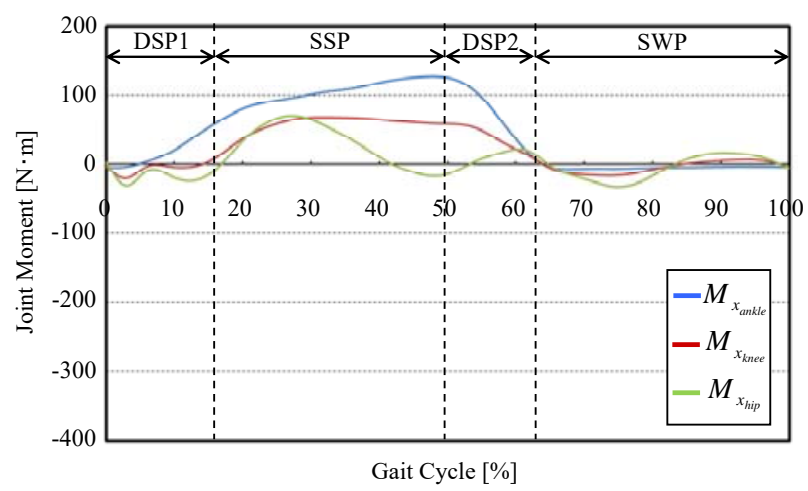

Fig. 22 Patterns of each joint moment in healthy subject. Gait cycle is divided into dsp1, ssp, dsp2 and swp.

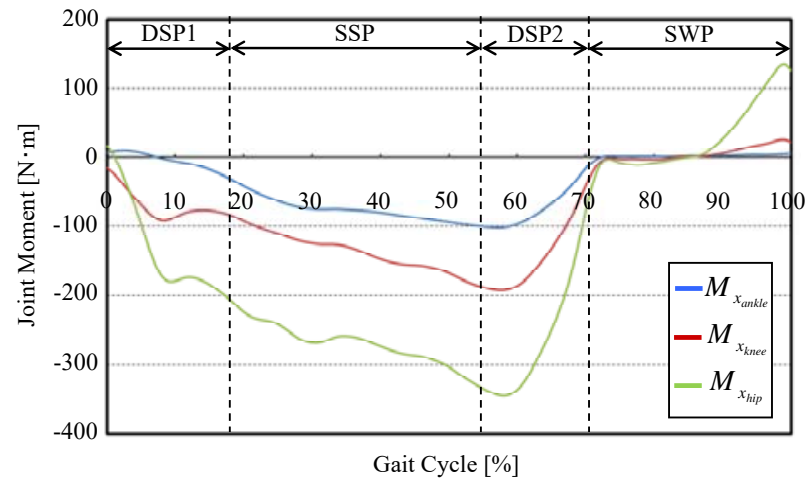

Fig. 24 Patterns of each joint moment in trans-femoral amputee. Gait cycle is divided into dsp1, ssp, dsp2 and swp.

\section{5. 結 言}

本研究では，ヒトの歩行などに生じる下肢の各関節における回転運動を定量的に解析および評価するため，従 来用いられていた運動変位である関節角度のみに関して特異值分解を施し主要な関節間協調を表す動作パターン を抽出する方法に対して，運動を生じさせる関節モーメントについても含めた新たな解析手法を提案した。提案 手法の適用例として，移動式床反力計および姿勢センサによるウェアラブルな計測装置と左右分離式トレッドミ ルを組み合わせ，健常者および大腿義足装着者を被験者とする歩行計測実験の結果を時系列形式にまとめ，デー 夕解析に用いた．具体的には，得られた床反カデータの挙動からヒトの一歩行周期を 4 フェーズに分け，関節間 協調動作の中でも相関が高い動作パターンを抽出し, それぞれを比較考察した結果, 以下に示す結論が得られた. 
1. 健常者と大腿義足装着者の歩行運動に関する相互比較では, 各関節角度に関しては同様の傾向がみられたが, 各関節モーメントに関しては特に足関節・膝関節において大きな違いがみられ，大腿義足装着者では不安定な 義足側のバランスや推進力を補った影響が健足側に出ており健常者とは異なる傾向を示したと考えられる.

2. 提案手法により関節角度・モーメントの双方を含めた健常者と大腿義足装着者の歩行運動に関する解析および 評価を通じて, 関節角度のみでは示せない関節モーメントの考慮による被験者間の明確な相違点を表す主要な 運動パターンを抽出し, 身体に関する生体力学的観点からの比較考察に基づき, それらの特徴を把握すること により，本研究において提案した歩行中の下肢関節回転運動に関する定量的解析手法の有効性を検証できた.

\section{謝 辞}

なお，本研究の一部は日本学術振興会 科学研究費助成事業 基盤研究 (B)（研究課題番号：25289053）の補助 を受けた。ここに記して謝意を表する.

\section{文献}

足立渡，辻内伸好，小泉孝之，塩島康造，土屋陽太郎，井上喜雄，携帯型床反力計およびモーションセンサを用 いた歩行解析システムの開発，日本機械学会論文集 C 編，Vol. 78, No. 789 (2012),pp. 1607-1616.

舩戸徹郎, 青井伸也, 土屋和雄, ヒトの歩行における全身の関節協調動作の定量的評価, 日本ロボット学会誌, Vol. 28, No. 8 (2010), pp. 996-1003.

舩戸徹郎, 青井伸也, 富田望, 土屋和雄, 運動学シナジーに基づくヒトの歩行制御構造の構成論的理解, 日本口 ボット学会誌，Vol. 31, No. 8 (2013), pp. 739-746.

Funato, T., Aoi, S., Tomita, N. and Tsuchiya, K., Validating the feedback control of intersegmental coordination by fluctuation analysis of disturbed walking, Experimental Brain Research, Vol. 233, No. 5 (2015), pp. 1421-1432.

林祐一郎, 辻内伸好, 小泉孝之, 松田靖史, 土屋陽太郎, 井上喜雄, 移動式床反力計を用いた制約のない健常者 および大腿切断者の歩行運動解析，日本機械学会論文集 C 編，Vol. 79, No. 805 (2013), pp. 3059-3074.

林祐一郎, 辻内伸好, 松田靖史, 関節間協調に基づく大腿義足着用者の主要な歩行運動パターンの定量的評価, 日本機械学会論文集, Vol. 81, No. 825 (2015), DOI : 10.1299/transjsme.15-00020.

Ivanenko, Y. P., d'Avella, A., Poppele, R. E. and Lacquaniti, F., On the origin of planar covariation of elevation angles during human locomotion, Journal of Neurophysiology, Vol. 99, No. 4 (2008). pp. 1890-1898.

北村徹, 辻内伸好, 小泉孝之, 筋電信号による動作推定に基づくロボットハンドのマニピュレーション，日本機 械学会論文集 C 編，Vol. 73, No. 735 (2007), pp. 3024-3030.

三嶋賢一，金田さやか，中西弘明，椹木哲夫，堀口由貴男，特異值分解を用いた動作における個人間の類似と差 異の抽出，電子情報通信学会論文誌 A，Vol. J94-A, No. 4 (2011), pp. 293-302.

Riley, O. P., Paolini, G., Croce, D. U., Paylo, W. K. and Kerrigan, C. D., A kinematic and kinetic comparison of overground and treadmill walking in healthy subjects, Gait \& Posture, Vol. 26, No. 1 (2007), pp. 17-24.

佐藤成登志, 林豊彦, 中村康雄, 逆動力学解析法を用いた片麻痺患者の上肢運動機能評価システム, バイオメカ ニズム学会誌, Vol. 32, No. 4 (2008), pp. 221-228.

豊田輝，山崎裕司，加藤宗規，宮城新吾，吉葉崇，練習方法の違いが模擬大腿義足歩行技能に及ぼす影響につい て, 理学療法科学, Vol. 23, No. 1 (2008), pp. 67-71.

Zatsiorsky, V., The mass and inertia characteristics of the main segments of the human body, Biomechanics VIII-B (1983), pp. 1152-1159.

\section{References}

Adachi, W., Tsujiuchi, N., Koizumi, T., Shiojima, K., Tsuchiya, Y. and Inoue, Y., Development of walking analysis system using by motion sensor with mobile force plate, Transactions of the Japan Society of Mechanical Engineers, Series C, Vol. 78, No. 789 (2012), pp. 1607-1616 (in Japanese).

Funato, T., Aoi, S. and Tsuchiya, K., Quantitative evaluation of the intersegmental coordination during human locomotion, Journal of the Robotics Society of Japan, Vol. 28, No. 8 (2010), pp. 996-1003 (in Japanese).

Funato, T., Aoi, S., Tomita, N. and Tsuchiya, K., Constructive approach towards understanding the control structure of human 
locomotion based on kinematic synergies, Journal of the Robotics Society of Japan, Vol. 31, No. 8 (2013), pp. 739-746 (in Japanese).

Funato, T., Aoi, S., Tomita, N. and Tsuchiya, K., Validating the feedback control of intersegmental coordination by fluctuation analysis of disturbed walking, Experimental Brain Research, Vol. 233, No. 5 (2015), pp. 1421-1432.

Hayashi, Y., Tsujiuchi, N., Koizumi, T., Matsuda, Y., Tsuchiya, Y. and Inoue, Y., Unrestrained human gait motion analysis of healthy subjects and trans-femoral amputee using mobile force plate, Transactions of the Japan Society of Mechanical Engineers, Series C, Vol. 79, No. 805 (2013), pp. 3059-3074 (in Japanese).

Hayashi, Y., Tsujiuchi, N. and Matsuda, Y., Quantitative evaluation concerning principal gait locomotion pattern of a trans-femoral amputee with a prosthetic limb based on the intersegmental coordination, Transactions of the JSME (in Japanese), Vol. 81, No. 825 (2015), DOI : 10.1299/transjsme.15-00020.

Ivanenko, Y. P., d'Avella, A., Poppele, R. E. and Lacquaniti, F., On the origin of planar covariation of elevation angles during human locomotion, Journal of Neurophysiology, Vol. 99, No. 4 (2008). pp. 1890-1898.

Kitamura, T., Tsujiuchi, N. and Koizumi, T., Manipulation of robot hand based on motion estimation using EMG signals, Transactions of the Japan Society of Mechanical Engineers, Series C, Vol. 73, No. 735 (2007), pp. 3024-3030 (in Japanese).

Mishima, K., Kanata, S., Nakanishi, H., Sawaragi, T. and Horiguchi, Y., Extraction of similarities and differences in human behavior using singular value decomposition, The Transactions of the Institute of Electronics, Information and Communication Engineers A, Vol. J94-A, No. 4 (2011), pp. 293-302 (in Japanese).

Riley, O. P., Paolini, G., Croce, D. U., Paylo, W. K. and Kerrigan, C. D., A kinematic and kinetic comparison of overground and treadmill walking in healthy subjects, Gait \& Posture, Vol. 26, No. 1 (2007), pp. 17-24.

Sato, N., Hayashi, T. and Nakamura, Y., A novel system for evaluating motor function of upper extremity in hemiplegic patients based on inverse dynamic analysis, Journal of the Society of Biomechanisms, Vol. 32, No. 4 (2008), pp. 221-228 (in Japanese).

Toyota, A., Yamasaki, H., Katou, M., Miyagi, S. and Yoshiba, T., The effect of difference in the practice methods on the gait skill using trial above-knee prosthesis, Rigakuryoho Kagaku, Vol. 23, No. 1 (2008), pp. 67-71 (in Japanese).

Zatsiorsky, V., The mass and inertia characteristics of the main segments of the human body, Biomechanics VIII-B (1983), pp. 1152-1159. 